\title{
Nutrient and sensory evaluation of traditional soups consumed in Igbere community in Bende local government area, Abia State, Nigeria
}

\author{
Obiakor-Okeke, P. N. ", Obioha, B. C., Onyeneke, E. N. \\ Faculty of Health Sciences, Department of Nutrition and Dietetics, Imo State University, PMB 2000, Owerri, Imo State Nigeria
}

\section{Email address:}

ngoziobiakor2001@yahoo.com (Obiakor-Okeke P. N.)

\section{To cite this article:}

Obiakor-Okeke, P. N., Obioha, B. C., Onyeneke, E. N.. Nutrient and Sensory Evaluation of Traditional Soups Consumed in Igbere Community in Bende Local Government Area, Abia State, Nigeria. International Journal of Nutrition and Food Sciences.

Vol. 3, No. 5, 2014, pp. 370-379. doi: 10.11648/j.ijnfs.20140305.12

\begin{abstract}
This study evaluated the proximate and micronutrient composition of traditional soups (Nsala, Achara, Ofeose and Uha) consumed in Igbere community, Abia Sate. The proximate composition, vitamin and mineral composition of the soups were determined using standard assay techniques. The protein content of the soup meals ranged from 31.77 to $40.20 \%$. The Achara soup had the highest protein content $(40.20 \%)$. The ash content of ofe-ose $(6.25 \%)$ was significantly higher $(\mathrm{p}<0.05)$ than the other soups $(5.62 \%, 5.33 \%$ and $4.98 \%)$ achara, nsala and Uha soups respectively. The fat content of ofe-ose $(11.25 \%)$ was significantly higher $(\mathrm{p}<0.05)$ than the other soups $(10.74 \%, 8.20$ and $9.77 \%)$ Uha, Nsala, and achara soups respectively. The fibre content of achara soup $(13.72 \%)$ was significantly higher $(\mathrm{p}<0.05)$ than the other soups(12.75\%. $8.20 \%$ and $10.77 \%$ ), ofe-ose. Nsala and Uha soups respectively. The vitamin A ranged from 3.49 to $687.69 \mathrm{mg}$ and there was no significant difference. The vitamin $\mathrm{C}$ content of the soups varied, it ranged from 4.11 to $41.07 \mathrm{mg}$, there was no significant difference in Achara, Nsala, Ofe and Uha (32.85mg, $4.11 \mathrm{mg}, 21.71 \mathrm{mg}$ and $41.07 \mathrm{mg}$ ) . The calcium content of ofe-ose $(41.42 \mathrm{mg})$ was Significantly $(\mathrm{p}<0.05)$ lower than the other soups, $(69.47 \mathrm{mg}, 74.8 \mathrm{Img}$, and $57.45 \mathrm{mg}$ ), Achara, Nsala and Uha soups respectively. The iron content of the soups varied and ranged from 0.23 to $0.43 \mathrm{mg} / 100 \mathrm{~g}$. The copper content ranged from 0.08 to $0.25 \mathrm{mg}$. The magnesium content of Ofe-ose (37.6mg) was significantly higher $(\mathrm{p}<0.05)$ then other soups, $(20.0 \mathrm{mg}, 25.6 \mathrm{mg}$ and $18.4 \mathrm{mg})$ Achara, Nsala and Uha soups respectively. The potassium content of the four soups were moderately high. They ranged from 48.13 to $118.93 \mathrm{mg}$. The phosphorus content of Uha $(199.85 \mathrm{mg})$ was significantly higher $(\mathrm{p}<0.05)$ than other soups, $(188.15 \mathrm{mg} 55.25 \mathrm{mg}$ and $54.17 \mathrm{mg}$ respectively. The zinc content of ofe-ose $(0.396 \mathrm{rng})$ was significantly higher $(\mathrm{p}<0.05)$ than other soups, $(0.364 \mathrm{mg} 0.23 \mathrm{mg}$ and $0.224 \mathrm{mg}$ ), Achara, Nsala and Uha soups respectively. Sensory evaluation conducted revealed that all the soups were generally acceptable. Consumption of these soups should be popularized for other communities to use since they are vegetable based and ideal for therapeutic nutrition.
\end{abstract}

Keywords: Nutrient, Sensory Evaluation, Traditional Soups, Igbere Community

\section{Introduction}

Lack of nutrition education precipitates wrong choice of food and malnutrition. The Interrelationship between diet, food habits and micronutrient deficiency disease have called for urgent investigation on the nutrient content of traditional soups consumed in various parts of Nigeria including in Igbere Land. In Nigeria, diets are high in carbohydrate and low in protein (1).

Deficiencies of micronutrients are a major global health problem. More than 2 billion people in the world today are estimated to be deficient in key vitamins and minerals, particularly vitamin A, iodine, iron and zinc. Most of these people live in low income countries and are typically deficient in more than one micronutrient. Deficiencies occur when people do not have access to micronutrient-rich foods such as fruit, vegetables, animal products and fortified foods, usually because they are too expensive to buy or are locally unavailable (2). Micronutrient deficiencies increase the general risk of infectious diseases because of compromised immune system as well as the risk 
of dying from diarrhoea, measles, malaria and pneumonia. These conditions are among the 10 leading causes of disease in the world today (3).

The groups most vulnerable to micronutrient deficiencies are pregnant women, lactating women, women of reproductive age and young children, mainly because they have a relatively greater need for vitamins and minerals and are more susceptible to the harmful consequences of deficiencies. However, for a pregnant woman these include a greater risk of dying during childbirth, or of giving birth to an underweight or mentally-impaired baby. As well for a lactating mother, her micronutrient status determines the health and development of her breast-fed infant, especially during the first 6 months of life. More so, for women of reproductive age group, the risk of iron deficiency and hence anaemia due to monthly menstrual cycle is increased as well as other consequences associated with iron deficiency and anaemia. Lastly for a young child, micronutrient deficiencies increase the risk of dying due to infectious disease and contribute to impaired physical and mental development $(2,4)$.

Apart from poor feeding practices and shortfalls in food intake, micronutrient deficiency is a direct cause of child morbidity and mortality. Micronutrients such as iron, iodine, vitamin A, are necessary for the healthy development of children. Their absence in the diet cause serious disorders. For example, lack of sufficient iodine can lead to goiter, hypothyroidism, mental and physical impairment. Damages due to iodine deficiency can be avoided by ensuring that the salt used in households is iodized (5).

In Nigeria, important progress has been made in Micronutrient deficiency control over the last years. Today Nigeria is justifiably considered Africa's success story on iodization of edible salt. It is the only sub-Saharan country to attain universal Salt iodization with about $97 \%$ of the households using iodized salt. This was confirmed by an external review carried out by the Global Network for Sustainable Elimination of Iodine Deficiency in 2005. Vitamin A is a crucial micronutrient for the development of children's immune and visual systems $(5,6)$. According to the Vitamin and Mineral Damage Assessment Report (5), $25 \%$ of the Nigerian children are growing up with lower immunity, leading to frequent ill health and poor growth due to vitamin A deficiency. Only $27 \%$ of Nigerian children between 6 months and five years receive Vitamin A supplements routinely through health facilities although an average of $70 \%$ received Vitamin A capsules during the National Immunization Days (5).

The individual diet is a primary vehicle for his/her interaction with the environment. It is the major source of nutrient, and can be a significant source of human exposure to infections; toxic and pharmacological agents. To maintain optimal nutritional status, an individual must consume diets adequate in quality and quantity. The nutritional status of a community depends to a large extent on the diets consumed. Food availability and food habit's differs from community to community hence emphasis on local dishes should be made in order to achieve adequate growth, development and reproduction.

It is known that about $30 \%$ of the population in developing counties are currently suffering from one or more of the multiple forms of nutritional deficiencies, especially micronutrient (6). The major nutritional problem in these countries are insufficient intake of food nutrients which are related to food insecurity, diseases, lack of care and excessive or unbalanced food intake and/or particular dietary constituent. Social factors and cultural practices in most communities greatly influence what the people consume, how they prepared their food, their feeding practices and choice of food (7).

The traditional soup meals of most societies are good and only minor modifications are needed for them to meet the nutrient requirements of all members of family (7). The starchy foods are by far the most frequently consumed food in Nigeria especially among the low income groups. However, legumes and cereals provide the greatest contribution of plant protein and other nutrients. There is need to increase the production and consumption of major staples including vegetable which would help to bridge the gap between protein, energy and other nutrients. Inadequate nutrient intake predisposes to poor nutrition and chronic diseases. Deficiency disease caused by lack of such nutrients have been reported among the low income class in some parts of the country (1).

There has been no studies on the nutritional quality of indigenous soups in Igbere community of Abia State. Based on these facts, a good knowledge of the nutritionally quality (adequacy) of soups eaten in Igbere community and their preparation has necessitated the need for this study. Soup is a primarily liquid food, generally served warm (but may be cool or cold), that is made by combining ingredients such as meat and vegetable with stock, juice, water, or another liquid.

There is great need for all Nigerians to know the nutrient composition of their local foods. Our local soups are neglected in meal planning because information is lacking on their nutrient composition and as such, protein energy malnutrition and micronutrient deficiencies results. Some of these soups are rich in protein, calorie, vitamin and other components. As such there is need for the diversification and adequate consumption of the traditional foods and their products to combat PEM and micronutrient deficiencies. The knowledge of the nutritional composition of traditional soups will ease therapeutic meal planning and service.

The general objective of the study is to assess and determine the nutrient composition of traditional soups consumed in Igbere community in Bende local government area of Abia state. Specifically, the study is aimed to:

1. Prepare four traditional soup meals consumed in Igbere community of Abia state.

2. To assess the Nutrient (proximate and mineral vitamin composition of the soup meals.

3. To evaluate the organoleptic attributes of the soup meals. 
The output of this work would serve as a baseline for nutrient composition and assessment of soup meal specifically consumed in Igbere community. There is little information on the nutrient composition of Nigerian diet and foods especially those consumed in Igbere community of Abia State. It would therefore add to the knowledge base on composition of Nigeria foods.

\section{Methodology}

\subsection{Source of Materials}

Four vegetable species used for this include, Uha (Pterocapus specie), Achara (Pannisetum purpurem), Cocoyam leaves (Dioscorea specie), and okazi Leaf (Gentum africana) the leaves were collected/purchased from Nkwo Igbere market in Bende L.G.A of Abia State.

\subsection{Sample Preparation}

The vegetable leaves used for the studies were harvested fresh. The sensory evaluation was done at the department of Nutrition and Dietetics, Imo state University, whereby each soup samples (4 in numbers), were collected in a plastic container. The chemical analysis was done at the National Root Crop Research Institute (NRCRI) Umudike, Umuahia South L.G.A of Abia State.

\subsection{Collections of Samples}

Each soup sample (4 in number) were collected in a plastic container. The soup ingredients quantities and methods used in soup preparation were recorded below. The collected samples were stored in a deep freezer until used for analysis.

\subsection{Soup Preparation}

Uha leaves were plucked from the stalk, washed and shredded. Achara, the fleshy leaf Achara was cut off from its stalk. The edible part of the stalk or stem was obtained for preparation of soup. The newly sprouted cocoyam leaves were plucked from its stem, washed, tied together and separated for preparation of the soups. Okazi leaves were plucked from the stalk, washed and shredded for Nsala soup.

The soup ingredients such as Dry fish, Cray fish, stock fish, smoked fish and chicken was boiled together with onious, maggi, salt, and pepper and shared into four places for the soup preparation. Then pepper, ukpor, usu, yam, were grounded separately.

\subsubsection{Soup Preparation (Uha Soup)}

Table 1. List and quantities of ingredients used in soup preparation

\begin{tabular}{ll}
\hline Ingredient & Quantity used \\
\hline Uha leaves & $100 \mathrm{~g}$ \\
$\begin{array}{l}\text { Dry Fish, stock fish, smoked fish, Cray } \\
\text { fish, and chicken }\end{array}$ & $200 \mathrm{~g}$ \\
\hline
\end{tabular}

\begin{tabular}{ll}
\hline Ingredient & Quantity used \\
\hline Palm oil & $50 \mathrm{~g}$ \\
Dry pepper & $10 \mathrm{~g}$ \\
Ukpor (Mucuna flagellipes) & $10 \mathrm{~g}$ \\
Maggi & I cube \\
Salt & To taste \\
\hline
\end{tabular}

Method: A pot of the boiled ingredient was put on a hot plate heater and allowed to boil, after $100 \mathrm{~g}$ of water was added and allowed to boil for 5 minutes, palm oil was added and allowed to boil, then dry pepper, grounded ukpor and other ingredient was add and allowed to boil very well and after that the Uha leave was added and served.

\subsubsection{Ofe-ose Preparation}

Table 2. Ingredients and quantities used in soup preparation

\begin{tabular}{ll}
\hline Ingredient & Quantity used \\
\hline Cocoyam leaves & $100 \mathrm{~g}$ \\
$\begin{array}{l}\text { Dry Fish, stock fish, smoked fish, Cray } \\
\text { fish, and chicken }\end{array}$ & $200 \mathrm{~g}$ \\
Palm oil & $50 \mathrm{~g}$ \\
Egusi (melon) and usu (mixed) & $85 \mathrm{~g}$ \\
Dry pepper & $10 \mathrm{~g}$ \\
Maggi & I cube \\
Salt & To taste \\
\hline
\end{tabular}

Method: A pot of the boiled ingredient was put on a hot plate heater and was added $100 \mathrm{~g}$ of water and allowed to boil. After that the egwsi mixed with usu was added and allowed to boil for 5 minutes after that oil, dry pepper, magi and salt was added and allowed to boil very well and after that the' cocoyam leaves was added and was allowed to boil before serving.

\subsubsection{Nsala Soup with Okazi Leave}

Table 3. Ingredients and quantities used in soup preparation

\begin{tabular}{ll}
\hline Ingredient & Quantity used \\
\hline Okazi leaves & $100 \mathrm{~g}$ \\
Dry Fish, stock fish, smoked fish, & $200 \mathrm{~g}$ \\
Cray fish, and chicken & $85 \mathrm{~g}$ \\
Yam slice & $5 \mathrm{~g}$ \\
Ehuru \& Uziza seed & $10 \mathrm{~g}$ \\
Dry pepper & I cube \\
Maggi & To taste \\
Salt & \\
\hline
\end{tabular}

Method: A pot of boiled ingredients (meat \& fish) was put on a hot plate heater and allowed to boil, then $100 \mathrm{~g}$ of water was added and allowed to boil after that the pounded yam that was soft resilient dough was added and allowed for 5 minutes after that Ehuru and Uziza was added, pepper, maggi was added and allow for another 5 minutes then Okazi was added, salt was added to taste and served. 


\subsubsection{Achara Soup Preparation}

Table 4. List of ingredient and quantities used in preparation of Achara Soup

\begin{tabular}{ll}
\hline Ingredient & Quantity used \\
\hline Achara & $100 \mathrm{~g}$ \\
Dry Fish, stock fish, smoked fish, Cray & $200 \mathrm{~g}$ \\
fish, and chicken & $75 \mathrm{~g}$ \\
Egwusi (Cucurris melon) & $10 \mathrm{~g}$ \\
Ukpor (Mucuna flagellapes) & $10 \mathrm{~g}$ \\
Dry pepper & I cube \\
Maggi & To taste \\
Salt & \\
\hline
\end{tabular}

Method: A pot of the boiled ingredients was put on a hot plate heater and allowed to boil. And after that $100 \mathrm{~g}$ of water was added and allowed to boil for 5 minutes, palm oil was added and allowed to boil, then dry pepper, ground ukpor and Egwsi was added, after that maggi, salt was added and allowed to boil for another 5 minutes after that the Achara was added and served.

\subsection{Data Analysis}

All determinations were done in triplicates. The methods described below were used for the specific analysis. .

\subsection{Proximate Analysis}

\subsubsection{Moisture Determination}

This was done by the gravimetric method (8). A measured weight of the sample $(5.0 \mathrm{~g})$ was weighed into a previously weighed moisture can. The sample in the can was dried in the oven at $105^{\circ} \mathrm{C}$ for 3 hours. It was cooled ina desiccators and weighed. It was then returned to the oven for further drying. Drying, Cooling and weighing were done repeatedly at hourly (one hour) interval until there were no further diminutions in the weight (ie constant weight was obtained).

The weight of moisture lost was calculated' and expressed as a percentage of the weight of sample analyzed. It was given by the expression below.

$$
\% \text { Moisture content }=\frac{100}{1} \times \frac{\mathrm{W}_{2-} \mathrm{W}_{3}}{\mathrm{~W}_{2-} \mathrm{W}_{1}}
$$

Where $\mathrm{W}_{1}=$ Weight of empty moisture can $\mathrm{W}_{2}=$ Weight of empty can + sample before dying $\mathrm{W}_{3}=$ Weight of can + sample dried to constant weight.

\subsubsection{Determination of Protein}

This was done by the Kjeldah method described by James (9). The total Nitrogen was determined and multiplied with factor 6.25 to obtain the protein procedures.

Half gramme $(0.5 \mathrm{~g})$ of the sample was mixed with $10 \mathrm{mls}$ of Cone. $\mathrm{H}_{2} \mathrm{SO}_{4}$ in a digestion flask. A tablet of selenium catalyst was added to it before it was heated under a fume cupboard until a clear solution was obtained (i.e. the digest).
The digest was diluted to $100 \mathrm{mls}$ in a volumetric flask and used for the analysis.

$10 \mathrm{mls}$ of the digest was mixed with equal volume of $45 \%$ $\mathrm{NaOH}$ solution in a kjeldahl distillation apparatus. The mixture was distilled into $10 \mathrm{ml}$ of $4 \%$ buric acid containing 3 drops of mixed indicator (bromocressol green/methyl red) a total of $50 \mathrm{mls}$ of distillate was collected and titrated against $0.02 \mathrm{~N}$ EDTA from green to a deep red end point. A reagent blank was also digested, distilled and titrate. The $\mathrm{N}_{2}$ content and hence the protein content was calculated using the formula below.

$$
\begin{gathered}
1 \text { Mole of } \mathrm{INH}_{2} \mathrm{SO}_{4}=14 \mathrm{mgN}_{2} \\
\% \text { Protein }=\% \mathrm{~N}_{2} \times 6.25 \\
\% \mathrm{~N}_{2}=\left[\frac{100}{\mathrm{~W}} \times \frac{\mathrm{N} \times 14}{1000} \times \frac{\mathrm{Vt}}{\mathrm{Va}}\right] \mathrm{T}-\mathrm{B}
\end{gathered}
$$

$\mathrm{W}=$ Weight of sample $(0.5 \mathrm{~g})$

$\mathrm{N}=$ Normality of titrant $\left(0.02 \mathrm{~N} \mathrm{H}_{2} \mathrm{SO}_{4}\right.$

$\mathrm{Vt}=$ Total digest volume $(100 \mathrm{mls})$

$\mathrm{Va}=$ volume of digest analyzed $(10 \mathrm{ml})$

$\mathrm{T}=$ Sample titre value

$\mathrm{B}=$ Blank titre value

\subsubsection{Determination of Ash}

This was done by the furnaces incineration gravimetric method James (9). Five grammes $(5.0 \mathrm{~g})$ of the processed sample was measured into a previously weighed porcelain crucible. The sample was burnt to ashes in a muffle furnace at 550oc.when it has become completely ashed, it was cooled in a desiccators and weighed. The weight of ash obtained was calculated by difference and expressed as a percentage of the weight of sample analyzed as shown below.

$$
\% \text { Ash }=\frac{100}{1} \times \frac{\mathrm{W}_{2}-\mathrm{W}_{1}}{\text { Wt of Sample }}
$$

Where $\mathrm{W}_{1}=$ Weight of empty crucible

$\mathrm{W}_{2}=$ Weight of crucible + ash

\subsubsection{Determination of Crude Fibre}

The Wende Method $(8,9)$ was employed. $5.0 \mathrm{~g}$ of the processed sample was boiled in $150 \mathrm{mls}$ of $1.25 \% \mathrm{~N} 2 \mathrm{~S} 04$ solution for 30 minutes under reflux. The boiled sample was washed in several protons of hot water using a twofold Muslim cloth to trap the particles. It was returned to the flask and boiled again in $150 \mathrm{mls}$ of $1.25 \% \mathrm{NaOH}$ for another 30minuts under same condition. After washing in several- portion of hot water, the sample was allowed to drain dry before being transferred quantitatively to a weighed crucible where it was aried in the over at 10Soc to a constant weight. It was thereafter taken to a muffle furnace in which it was burnt until only ash was left of it. By difference, the weight of fibre was obtained and expressed as a percentage of the weight of sample analyzed.

It was given by the formular below. 


$$
\% \text { Crude fibre }=\frac{100}{1} \times \frac{\mathrm{W}_{2}-\mathrm{W}_{3}}{\mathrm{Wt} \text { of Sample }}
$$

Where $\mathrm{W}_{2}=$ Weight of crucible + sample after boiling, washing and drying

$\mathrm{W}_{3}=$ Weight of crucible + sample as ash

\subsubsection{Determination of Fat}

The solvent extraction gravimetric method $(8,9)$ was used, $5.0 \mathrm{~g}$ of the sample was wrapped in a porous paper (Whiteman filter paper) and put in a thimble, The thimble was put in a soxlet reflux flask and mounted into a weigh extraction flask containing $200 \mathrm{mls}$ of petroleum ether. The upper end of the reflux flask was connected to a water condenser. The solvent (petroleum ether) was heated; it boiled, vaporized and condensed into the reflux flask. Soon the sample in the thimble was covered with the solvent, which contract the oil (fat). The sample remained in contact with the solvent until the reflux flask filled up and siphoned over, carrying its oil extract down to the boiling flask. This process was allowed to go on repeatedly for 4 hours before the defatted sample was removed, the solvent recovered and the oil extract was in the flask. The flask (containing the oil extract), was dried in the oven at $60^{\circ} \mathrm{C}$ for $30 \mathrm{mins}$ (to remove any residual solvent). It was cooled in desiccators and weighed. By difference, the weight of oil (fat) extract was determined and expressed as a percentage of the weight of sample analyzed and given by the expression .below:

$$
\% \mathrm{Fa}=\frac{\mathrm{W}_{2}-\mathrm{W}_{1}}{\mathrm{Wt} \text { of Sample }} \times \frac{100}{1}
$$

Where $\mathrm{W}_{1}=$ Weight of empty extraction flask

$$
\mathrm{W}_{2}=\text { Weight of flask }+ \text { oil (fat) extract }
$$

\subsubsection{Determination of Carbohydrate}

It was calculated using the formular below as described by James (9)

$$
\begin{gathered}
\% \text { carbohydrate }=100 \%(\text { protein }+ \text { fat }+ \text { fibre }+ \text { ash }+ \\
\text { moisture content })
\end{gathered}
$$

\subsection{Determination of Mineral}

Mineral content of the sample was done following the dry ash extraction method $(8,9,11)$.

A measured weight of the sample was burnt to ashes (as in ash determination) thereby removing all the organic materials leaving the inorganic ash. The resulting ash was dissolved in $5 \mathrm{mls}$ of dilute $(0.1 \mathrm{~m}) \mathrm{HCl}$ solution and then diluted to $100 \mathrm{mls}$ in a volume flask. This extracts was used in specific analysis for the different mineral elements.

\subsubsection{Determination of Potassium by Flame Photometry}

The instrument, Jaway digital flame photometer, was set up according to the manufactures instruction. It was switched on and allowed about 10 to 15 minutes to equilibrate. Mean while standard potassium solution were prepared and diluted in series to contain 10, 8, 6, 4, and 2pp of $\mathrm{K}$.

After calibrating the instrument, $1 \mathrm{ml}$ of each standard was aspirated into it and sprayed over the non-luminous flame. The optical density of the resulting emission from standard solution was recorded. Before flaming, the appropriate element fitter $(\mathrm{K})$ was put in place with the standards measured, the test sample extracts were measured in time and there were plotted into standard curse which was used to extrapolate the content of each test element and calculated as shown below:

$$
\mathrm{K}(\mathrm{mg} / 100 \mathrm{~g})=\frac{\mathrm{X}}{1000} \times \frac{\mathrm{Vf}}{\mathrm{Va}} \times \mathrm{DX} \times \frac{100}{\mathrm{~W}}
$$

Where $\mathrm{X}$ is the concentration of the test element from the curve.

\subsubsection{Determination of Phosphorus}

Phosphorus in the test sample was determined by the molybdo vanadate colorimetric method $(9,10,11)$. A measured volume of the dry ash $(2 \mathrm{mg})$ digest of the samples was dispersed into a $50 \mathrm{ml}$ volume flask. At the samples time, the same volume of distilled water rand standard $\mathrm{p}$ solution were measured into different flask to serve as reagent blank and standard respectively. $2 \mathrm{mls}$ of the phosphorus color reagent (molybdo vanadate solution) was added to each of the, flask and allowed to stand at room temperature for 15 minutes. Content of each flask was diluted to the $50 \mathrm{ml}$ mark with distilled water and its absorbance was measured in a spectrophotometer at a wavelength of $5401 \mathrm{~m}$ with the reagent blank at zero.

The phosphorus content was calculated using the formular below:

$$
\mathrm{K}(\mathrm{mg} / 100 \mathrm{~g})=\frac{100}{\mathrm{~W}} \times \frac{\mathrm{au}}{\mathrm{as}} \times \mathrm{C} \times \frac{\mathrm{Vt}}{\mathrm{Va}}
$$

Where $\mathrm{W}=$ Weight of sample ashes

$\mathrm{Au}=$ Absorbance of test sample

As $=$ Absorbance of standard phosphorus solution,

$\mathrm{C}=$ Concentration of standard phosphorus solution

$\mathrm{Vt}=$ Total extract volume

$\mathrm{Va}=$ Volume of extract analyzed

\subsubsection{Determination of Calcium and Magnesium by Complexiometric Titration}

The versanate EDT A titrimetric method was employed $(9,10) .20 \mathrm{ml}$ portion of the extract was dispersed into conical flask and treated with pinches of the masking agents (hydroxylamine hydrochloride, sodium cyanide and sodium potassium ferrocyanide). The flask was shaken and the mixture dissolved $20 \mathrm{mls}$ of ammonia buffer was added to it be raise the $\mathrm{PH}$ to 10.00 (a point at which both calcium and magnesium form complexes with EDTA). The mixture was titrated against $0.02 \mathrm{~N}$ EDTA solution using eriochrome black $\mathrm{T}$ as indicator. A reagent blank was also titrated and titration in each case was done from deep red to a permanent blue end point. The titration value represent both 
$\mathrm{Ca}^{2+}$ alone in the test samples.

Titration of calcium alone was done in similarity with the above titration however, $10 \% \mathrm{fJAOH}$ was used in place of the ammonia buffer and solechrome Dark blue indicator in place of Eriochrome Black T. from the titre value obtained, the $\mathrm{Ca}^{2+}$ and $\mathrm{mg}^{2+}$ content were calculated as shown below: Where:

$\mathrm{W}=$ Weight of sample

$\mathrm{T}=$ Titre value of sample

$\mathrm{B}=$ Titre value of Blank

$\mathrm{C}=$ Calcium equivalence

$\mathrm{Mg}=$ Magnesium equivalence

$\mathrm{N}=$ Normality of titrant (0.02N EDT A)

\subsubsection{Determination of Zinc, Copper, and Iron}

The method of AOAC (8) was used $2 \mathrm{~g}$ of each sample was collected and. was added into HCL for preparation of stock solution.

Aliquot of the diluted clear digest was used for spectrophotometric reading. A standard solution of the different elements were prepared in concentration of 0.0 , $0.5,1.0$ and $1.5 \mathrm{ppm}$.

\section{Calculations}

$$
\begin{aligned}
& \mathrm{Zn}(\mathrm{mg} / 1000)=\frac{100}{\mathrm{~W}} \times \frac{\mathrm{X}}{10^{3}} \times \frac{\mathrm{Vf}}{\mathrm{Va}} \\
& \mathrm{Cu}(\mathrm{mg} / 1000)=\frac{100}{\mathrm{~W}} \times \frac{\mathrm{X}}{10^{3}} \times \frac{\mathrm{Vf}}{\mathrm{Va}} \\
& \mathrm{Fe}(\mathrm{mg} / 1000)=\frac{100}{W} \times \frac{\mathrm{X}}{10^{3}} \times \frac{\mathrm{Vf}}{\mathrm{Va}}
\end{aligned}
$$

$\mathrm{X}=$ Ppm off curve

$\mathrm{W}=$ Weight of sample used

$\mathrm{Vf}=$ Volume of total sample

$\mathrm{Va}=$ Volume of sample solution used

\subsection{Determination of Vitamins}

Vitamin A, C in the sample were determined using the method of the Association of vitamin chemists as described by Kirk and sawyer (11).

\subsubsection{Vitamin A Determination}

The method of the association of vitamin chemists (11) was employed. A measured weight $(5.0 \mathrm{~g})$ of the processed samples was dispersed, in $30 \mathrm{ml}$ of absolute alcohol $3 \mathrm{ml}$ of $5 \% \mathrm{KOH}$ solution was added to itand boiled under reflux for 30minal after cooling rapidly in running water, $30 \mathrm{ml}$, of distilled water was added to it and the mixture was transferred into a separation funnel. Three portion of $50 \mathrm{mls}$ of ether was used to wash the mixture thus extracting the vitamin A the lower layer (aqueous) was discarded while the vat A extract was washed with a $50 \mathrm{mls}$ distilled water. Care was taken to avoid formation of emulsion. The extract was then evaporated to dryness and dissolved in 10mls of isopropyl alcohol and its absorbance of the vitamin A extract was also measured at $325 \mathrm{~nm}$. The vitamin A content was calculated using the relationship below:

$$
\operatorname{Vitamin} A(m g / 1000)=\frac{100}{W} \times \frac{\mathrm{au}}{\mathrm{as}} \times C
$$

\subsubsection{Determination of Vitamin c. $(9,11)$}

Five grammes $(5 \mathrm{~g})$ of the sample was dispersed in $50 \mathrm{ml}$ of EDTAITCA solution and homogenized.

The homogenate was filtered, what man No 42 filter paper and more of the extractant was used to wash the residue in the filter paper until $50 \mathrm{ml}$ filtrate was obtained. A $20 \mathrm{ml}$ portion of the filtrate was measured into a conical flask and $10 \mathrm{ml}$ of $30 \% \mathrm{KT}$ solution was added to it mixed well and then followed by $1 \%$ starch solution. The mixture was triated against $0.01 \mathrm{~m} \mathrm{CuSO}_{4}$ solutions. A reagent blank was also titrated.

The vitamin $\mathrm{C}$ content was calculated based on the relationship that $1 \mathrm{~m} 10.01 \mathrm{~m} \mathrm{CuSO}_{4}=0.88 \mathrm{mg}$ vitamin $\mathrm{C}$.

$$
\begin{aligned}
& \text { Therefore vitamin } \mathrm{C} \mathrm{mg} / 100 \mathrm{~g} \\
& =\frac{100}{\mathrm{~W}} \times 0.88 \times(\mathrm{T}-\mathrm{B}) \times \frac{\mathrm{Vt}}{\mathrm{Va}}
\end{aligned}
$$

Where $\mathrm{W}=$ Weight of sample

$\mathrm{T}=$ Titre value of sample

$\mathrm{B}=$ Titre value of blank

$\mathrm{Vt}=$ Total extract volume

$\mathrm{Va}=$ volum of extract of extract titrated.

\subsubsection{Organoleptic Evaluation}

Organoleptic attributed (color, texture, aroma, mouth feel and general acceptability of the soup were evaluated using a nine point hedonic scale (12). Ten subjects who had participated in sensory evaluation of food products were selected as judges for the study. The judges were asked to taste each of the soup for color, mouth feel, aroma, texture and general acceptability and indicate their feeling about the product on the sensory evaluation sheet.

\subsection{Statistical Analysis}

Means and standard deviation were subjected to analysis of Variance (ANOVA) to see if there are significant difference among the four samples of soup in their proximate composition, mineral compositions and vitamin composition (13).

\section{Results}

The soups consumed in Igbere community include Ofeose, Achara, Nsala with Ukazi and Uha soup.

\subsection{Proximate Composition of Soups}


Table 5. Proximate composition of soups consumed in Igbere Community

\begin{tabular}{lllllll}
\hline Samples & Moisture (\%) & Ash (\%) & Protein (\%) & Fat (\%) & Fibre (\%) \\
\hline A & $54.96^{\mathrm{b}} \pm 0.79$ & $5.62^{\mathrm{b}} \pm 0.028$ & $40.20^{\mathrm{a}} \pm 0.06$ & $9.77^{\mathrm{b}} \pm 0.04$ & $13.72^{\mathrm{a}} \pm 0.01$ \\
B & $52.49^{\mathrm{c}} \pm 1.11$ & $4.94^{\mathrm{d}} \pm 0.028$ & $31.77^{\mathrm{c}} \pm 0.01$ & $8.20^{\mathrm{c}} \pm 0.05$ & $8.20^{\mathrm{d}} \pm 0.05$ \\
C & $57.88^{\mathrm{a}} \pm 0.84$ & $5.33^{\mathrm{c}} \pm 0.042$ & $39.39^{\mathrm{a}} \pm 0.01$ & $10.74^{\mathrm{ab}} \pm 0.05$ & $10.77^{\mathrm{d}} \pm 0.01$ \\
D & $56.86^{\mathrm{ab}} \pm 0.99$ & $6.25^{\mathrm{a}} \pm 0.014$ & $35.56^{\mathrm{b}} \pm 0.59$ & $11.25^{\mathrm{a}} \pm 0.69$ & $46.52^{\mathrm{a}} \pm 0.19$ & $34.12^{\mathrm{b}} \pm 0.015$ \\
\hline
\end{tabular}

$\mathrm{n}=4$

*a-d: Values with the same letters are statistically similar $(\mathrm{p}>0.05)$ and those with different letters are different $(\mathrm{p}<0.05)$

Mean \pm SD of 3 determinations

$\mathrm{CHO}=$ Carbohydrates

Where sample A is Achara soup

Sample B is Nsala soup

Sample C is Uha soup

Sample D is ofe- ose

The moisture content of the four soups varied. The values ranged from 52.49 to $57.88 \%$. The moisture content of Uha soup $(57.88 \%)$ is significantly $(\mathrm{P}<0.05)$ higher than Achara $(54.96 \%)$ and Nsala $(52.49 \%)$ soups but similar to Ofe-ose $(56.86 \%)$. The ash content of the soups ranged from 4.94 to $6.25 \%$. The ash content of Ofe-ose $(6.25 \%)$ is significantly $(\mathrm{P}<0.05)$ higher than the other soups while that of Uha soup is significantly lower than the other soups. The protein content of the four soups varied. It ranged from 31.77 to $40.20 \%$. The protein content of Achara soup $(40.20 \%)$ is similar to that of Uha soup (39.39\%) $(\mathrm{P}>0.05)$. The fat content of the four soups varied. It ranged from 8.20 to $11.25 \%$. The fat content of Ofe-ose $(11.25 \%)$ was significantly higher than other soups $(\mathrm{P}<0.05)$. The Nsala soup had the least fat content $(8.20 \%)$. The fibre content of the achara soup is significantly $(\mathrm{P}<0.05)$ higher $(13.72 \%)$ than the other soups while that of Nsala soup $(8.20 \%)$ is significantly $(\mathrm{P}<0.05)$ lower than the other soups. Among all the soups studied, the carbohydrate content of Nsala soup $(46.52 \%)$ is significantly higher than the other soups. However there is no significant $(\mathrm{P}>0.05)$ difference in Ofeose $(34.19 \%)$ and Uha soup (34.12\%).

\subsection{Vitamin Composition of the Soup}

Table 7. Mineral Composition of Soup Consumed in lqbere Community per $100 \mathrm{~g}$ Portion

\begin{tabular}{|c|c|c|c|c|c|c|c|}
\hline Samples & Potassium (mg) & Calcium (mg) & Magnesium (mg) & Phosphorus (mg) & Zinc (mg) & Iron (mg) & Copper (mg) \\
\hline $\mathbf{A}$ & $68.53^{\mathrm{a}} \pm 0.23$ & $69.47^{\mathrm{a}} \pm 2.30$ & $20.0^{c} \pm 1.39$ & $188.15^{\mathrm{b}} \pm 0.40$ & $0.364^{\mathrm{b}} \pm 0.004$ & $0.43^{\mathrm{a}} \pm 0.04$ & $0.24^{\mathrm{a}} \pm 0.04$ \\
\hline B & $85.47^{\mathrm{a}} \pm 0.23$ & $74.81^{\mathrm{a}} \pm 2.32$ & $25.6^{\mathrm{b}} \pm 1.39$ & $55.25^{\mathrm{c}} \pm 0.46$ & $0.23^{b c} \pm 0.03$ & $0.38^{\mathrm{a}} \pm 0.08$ & $0.08^{\mathrm{a}} \pm 0.06$ \\
\hline C & $118.3^{\mathrm{a}} \pm 0.46$ & $57.45^{\mathrm{b}} \pm 2.32$ & $18.4^{\mathrm{c}} \pm 1.39$ & $199.85^{\mathrm{a}} \pm 0.64$ & $0.224^{\mathrm{c}} \pm 0.004$ & $0.23^{\mathrm{a}} \pm 0.03$ & $0.23^{\mathrm{a}} \pm 0.03$ \\
\hline D & $48.13^{\mathrm{a}} \pm 0.83$ & $41.42^{c} \pm 2.32$ & $37.6^{\mathrm{a}} \pm 1.39$ & $54.17^{\mathrm{c}} \pm 2.06$ & $0.396^{\mathrm{a}} \pm 0.005$ & $0.37^{\mathrm{a}} \pm 0.06$ & $0.25^{\mathrm{a}} \pm 0.05$ \\
\hline
\end{tabular}

$\mathrm{n}=4$

*a-d: Values with the same letters are statistically similar $(\mathrm{p}>0.05)$ and those with different letters are different $(\mathrm{p}<0.05)$

Mean \pm SD of 3 determinations

Sample A -Achara soup

B-Nsala soup

C-Uha soup

D-Ofe-ose

The potassium, Iron and copper content of the four soups varied, however, there were no significant $(\mathrm{P}>0.05)$ difference among these nutrients in the four soup samples. The calcium contents of the four soups ranged from 41.42 to $74.81 \mathrm{mg}$. there is significant difference in calcium contents of the soups $(\mathrm{P}<0.05)$. The calcium content of Ofe-
Table 6. Vitamin Composition of Soups Consumed in Igbere Community

\begin{tabular}{lll}
\hline Samples & Vitamin A $(\mathbf{m g})$ & Vitamin C $(\mathbf{m g})$ \\
\hline A & $521.02^{\mathrm{a}} \pm 1.34$ & $32.85^{\mathrm{a}} \pm 1.01$ \\
B & $3.49^{\mathrm{a}} \pm 0.18$ & $4.11^{\mathrm{a}} \pm 1.02$ \\
C & $687.69^{\mathrm{a}} \pm 0.54$ & $41.07^{\mathrm{a}} \pm 1.02$ \\
$\mathbf{D}$ & $649.23^{\mathrm{a}} \pm 0.62$ & $21.71^{\mathrm{a}} \pm 1.02$ \\
\hline & \\
$\mathrm{n}=4$ & \\
*a-d: Values with the same letters are statistically similar $(\mathrm{p}>0.05)$ and \\
those with different letters are different $(\mathrm{p}<0.05)$ \\
Mean \pm SD of 3 determinations \\
Where sample A is Achara soup \\
Sample B is Nsala soup \\
Sample C is Uha soup \\
Sample D is ofe- ose
\end{tabular}

Vitamin C and A Composition of the four traditional soups consumed in Igbere Community are presented in table 6 there is no significant difference in the Vitamin content of the soups. The Vitamin A ranged from 3.49 to $687.69 \mathrm{mg}$ The vitamin A content of the soup varied, There is no significant $(\mathrm{P}>0.05)$ difference in (Achara $521.02 \mathrm{mg}$ ), Nsala $3.49 \mathrm{mg}, 687.69 \mathrm{mg}$, Ofe-ose $649.23 \mathrm{mg}$.

\subsection{Mineral Composition of the Soups}


higher $(\mathrm{P}<0.05)$ than the other soups, while Nsala is significantly higher $(\mathrm{P}<0.05)$ than Achara $(20.0 \mathrm{mg})$ and Uha $(18.4 \mathrm{mg})$ and there is no significant $(\mathrm{P}>0.05)$ difference between Achara (20.0mg) and Uha (18.4mg). The phosphorus content of the soups ranged from 54.17 to $199.85 \mathrm{mg}$. The phosphorus content of Uha (199.85mg) is significantly, higher $(\mathrm{P}<0.05)$ than the other soups, while Achara $(188.15 \mathrm{mg})$ higher $(\mathrm{P}<0.05)$ than Nsala $(55.25 \mathrm{mg})$ and Ofe-ose $(54.17 \mathrm{mg})$. However there is no significant $(\mathrm{P}>0.05)$ different between Nsala $(55.25 \mathrm{mg})$ and Ofe-ose (54.17mg).

The zinc content of the soups ranged from 0.224 to $0.396 \mathrm{mg}$. The zinc content of Ofe-Ose $(0.396 \mathrm{mg})$ is significantly $(\mathrm{P}<0.05)$ higher than other soups. While there is no significant $(\mathrm{P}>0.05)$ different between Achara $(0.364$ $\mathrm{mg})$ and that of Nsala $(0.23 \mathrm{mg})$. Also there is no significant $(\mathrm{P}>0.05)$ different between Nsala $(0.23 \mathrm{mg})$ and Uha (0.224).

\section{Organoleptic Evaluations}

Table 8. Organoleptic Properties of Soups Consumed in Igbere Community

\begin{tabular}{llllll}
\hline Sample & Color & Mouth Feel & Aroma & Texture & General Acceptability \\
\hline A & $77^{\mathrm{a}} \pm 0.02$ & $82^{\mathrm{a}} \pm 0.02$ & $84^{\mathrm{a}} \pm 0.02$ & $60^{\mathrm{a}} \pm 0.02$ & $74^{\mathrm{a}} \pm 0.01$ \\
B & $78^{\mathrm{a}} \pm 0.01$ & $79^{\mathrm{a}} \pm 0.01$ & $83^{\mathrm{a}} \pm 0.01$ & $36^{\mathrm{a}} \pm 0.02$ & $53^{\mathrm{a}} \pm 0.02$ \\
C & $74^{\mathrm{a}} \pm 0.01$ & $66^{\mathrm{a}} \pm 0.02$ & $77^{\mathrm{a}} \pm 0.02$ & $37^{\mathrm{a}} \pm 0.01$ & $56^{\mathrm{a}} \pm 0.01$ \\
D & $70^{\mathrm{a}} \pm 0.02$ & $68^{\mathrm{a}} \pm 0.01$ & $75^{\mathrm{a}} \pm 0.02$ & $35^{\mathrm{a}} \pm 0.02$ & $44^{\mathrm{a}} \pm 0.01$ \\
\hline
\end{tabular}

$\mathrm{n}=4$

*a-d: Values with the same letters are statistically similar $(\mathrm{p}>0.05)$ and those with different letters are different $(\mathrm{p}<0.05)$

Sample A -Achara soup

B-Nsala soup

C-Uha soup

D- Ofe-ose

The color of the soups varied. The color ranged from 70 to $78 \%$. And there was no significant difference. The month feel of the soups varied. The taste ranged from 66 to $82 \%$. However there is no significant difference. The Aroma of the soup ranged from 75 to $84 \%$ and there is no significant different between Achara (84\%), Nsala (83\%), Uha (77\%), and Ofe-ose $(75 \%)$. The texture of the soup ranged from 35 to $60 \%$ and there is no significant difference found in them. The General acceptability of the soups varied it ranged from 44 to $74 \%$. However there is no significant difference in Achara (74\%), Nsala (53\%), Uha (56\%) and Ofe-ose (44\%).

\section{Discussion}

The four traditional soup meals consumed in Igbere community Abia state were studied. The results of this present study are in line with earlier observation that food stuffs of vegetable origin are consumed in developing countries in quantities which contain most of the essential nutrients in excess of individual requirements (14). Uha had the highest moisture content of $57.88 \%$ followed by ofe-ose with a value of $56.86 \%$ while Nsala and Achara had the least value of $52.49 \%$ and $54.96 \%$ showing significant difference $(p>0.05)$ from the rest. The high levels of moisture in all the samples investigated suggests that the leafy vegetable would not store for long without spoilage since high water activity could enhance microbial action bringing about food spoilage. The moisture content of vegetable varies with locality and season hence the moisture content might not be unrelated with the season and climatic condition prevailing in the locality where the research was conducted.

The result of this work indicates that achara soup had higher fibre, content (13.72\%) than the other soups, this suggest that achara soup is a good source of fibre compared to other soups. However, achara being grass is a good source of roughage for ruminant animals and the components are not easily digested hence the roughages are high. The fibre content of the soup meals is slightly higher than the observation of Eka (16). The moderately high carbohydrate and slightly moderate fat content of the four soups increased the energy value of the meals. The higher fat content of ofe-ose (17.25\%) against those of Uha, Achara and Nsala soups $(10.7 \%, 9.77 \%$ and $8.20 \%$ respectively) might be attributed to more egwusi and little palm oil used during preparation.

Achara showed significantly higher protein content ( $>0.05$ ) compared to the other soup's while Nsala had the least protein content. In general soups need to be combined with other foods of high protein value in order to meet the protein requirements of individuals' (17). The higher ash content of ofe-ose $6.25 \%$ against those of achara, Nsala and Uha soups $(5.62 \%, 5.31 \%$ and $4.94 \%)$ suggests that ofe-ose is a better source of mineral and the Uha soup could not be used as a very good source of mineral though among the soups analysed, it has the highest content of potassium and phosphorus (see table 7). The low value of vitamin A content of Nsala soup $(3.49 \mathrm{mg}$ ) may be attributed its low content of palm oil which have been identified to be a good source of vitamin A. However, this result does not agree with that reported by Ene-obong (14). Furthermore Uha soup appears to be a good source of vitamin A due to its higher vitamin A content (687.69mg). The high vitamin $\mathrm{C}$ content of the soup meals suggests that the various vegetable used for the four soups during preparation are good sources of vitamin $\mathrm{C}$. The high vitamin $\mathrm{C}$ content of the soup meals is higher than that reported by purseglove 
(18) and Ene-obong (14). Similarly, the iron content and zinc content of the soup meals is lower than those reported by Ene-obong.

The ofe-ose has the highest copper content $(0.25 \mathrm{mg})$ than the other soups and this suggest that ofe-ose is a good source of copper, and this aid iron metabolism because copper is an integral part of ceruloplasmin that converts ferrous to ferric prior to its transportation via transferring. Copper also participates in Immune system, function, red and white blood cells maturation and cholesterol and glucose metabolism.

The high potassium, calcium, magnesium and phosphorus content of the four soup meals might be attributed by large quantities of vegetable used during preparation.

The sensory evaluation of the soups varied. The variations in the soups might be attributed by the vegetables used for the soup. However all the soups were statistically similar were accepted equally on the organoleptic characters tested.

\section{Conclusion}

In this study, it was observed that the soups consumed in Iqbere community are high in protein, vitamin A, vitamin $\mathrm{C}$, calcium, phosphorus, potassium, magnesium and carbohydrate but low in fiber, fat, zinc, iron \& Copper. However, Nsala and Uha soups had the least moisture content thus may have higher shelf life than the other soups. It was also identified that ofe-ose is a good source of crude fibre. Therefore, consumption of their soups may enhance the nutritional status of individuals. All the soups analysed in this study are nutritionally rich, all are recommended to be taken at different times since the nutrient densities differs and consumption of various kinds of foods ensures adequacy. It is also important to note the soups that are specifically high in various micro and macro nutrient tested during management of diseases in the case of restriction of a particular nutrient, hence this paper is a vital tool in the hand of dietitians in the hospitals where these soups are consumed.

\section{Recommendation}

1. There is an urgent need for Nigeria to put in Place food composition table for local foods especially local vegetables.

2. Economic growth and development depends on good health of citizens extensive, intensive nutrition education programe is imperative to improve the diets of the masses. Also extension agents who have knowledge of nutrition should disseminate the knowledge of nutrition to the rural communities and methods of preparation and processing to avoid nutrient loss for example The B vitamin's, vitamin $\mathrm{A}$ and vitamin $\mathrm{C}$.

3. Combination of vegetable to provide essential nutrients in adequate quantity and quality should be encouraged in both rural and urban dwellers. In order to reduce micronutrient deficiency diseases and protein energy malnutrition, regular consumption of these soup meals are recommended as judged by the results and should be incorporated in meal planning.

4. However, nutrition education programmes and workshop should be intesified in public health centers and civic centers to promote its food use and diversification.

\section{References}

[1] Onwueme, I.C. \&T.D. Sinha, (1991). Field Crop Production in Tropical Africa (Principles and Practice). Technical Centre for Agricultural and Rural Co-Operation CTA, Ede, Wageningen, The Netherlands.

[2] World Health Organization, World Food Programme \& United Nations Children's Fund (2007). Joint statement by the World Health Organization, the World Food Programme and the United Nations Children's Fund: Preventing and controlling micronutrient deficiencies in populations affected by an emergency Multiple vitamin and mineral supplements for pregnant and lactating women, and for children aged 6 to 59 months. Geneva, World Health Organization, 2007.

[3] The World Health Report (2001). Reducing risks, promoting healthy life. Geneva, World Health Organization, 2001.

[4] UNICEF/UNU/WHO (1999). Composition of a multiMicronutrient supplement to be used in pilot programmes among pregnant women in developing countries. Report of a Workshop. New York, UNICEF, 1999.

[5] UNICEF Nigeria, (2006).Information sheet on nutrition. UNICEF Nigeria

[6] FAO/WHO. Vitamin and mineral requirements in human nutrition, 2nd ed. Geneva, World Health Organization, 2005.

[7] Latham, M.C. (1997). Human nutrition in the developing world. FAO Food and Nutrition Series No. 29

[8] Association of Official Analytical Chemists (AOAC) (1995). Official methods of analysis $15^{\text {th }}$ ed. Washington DC, U.S.A.

[9] James C.S. (1995). Analytical Chemistry of Foods 1 edn, Chapman and Hall New York.

[10] Nwosu O. I. C., Nnam N. N., Ibeziako N. \& Maduforo A.N. (2014) Development and Nutritional Evaluation of Infant Complementary Food from Maize (Zea Mays), Soybean (Glycine Max) and Moringa Oleifera Leaves. International Journal of Nutrition and Food Sciences. Vol. 3, No. 4, 2014, pp. 290-299. doi: 10.11648/j.ijnfs.20140304.19

[11] Kirk, R. \& Sawyer, R. (1998). Pearson's composition and analysis of foods. Publ. Church Hill Livingstone, Edinbburgh.

[12] Ihekoronye, A.I. \& Ngoddy, P.O. (1985). Integrated Food Science and Technology, for the Tropics. Macmillan Publishing Ltd. London p.386. 
[13] Onuh, O. M. \& Igwemma, A. A. (2007); Applied Statistical Techniques for Business and Basic Sciences. Second Edition. Skillmark Media Ltd., Owerri. Pp. 261 - 301.

[14] Ene- Obong, H.N. \& Carnovale (1992) A comparison of the proximate, mineral and amino acid composition of some known and lesser-known legumes in Nigeria. Food Chemistry, 43, 169-175.

[15] Habiba, O., Ejoh, R., Ndjouenkeu, R. \& Tanya A. (2005). Nutrition Content of Complementary foods based on processed and fermented sorghum, groundnuts, spinach, and mango. Food and Nutrition Bulletin, 26, (4), 385-392(8).
[16] Oguntona, T.(1998). Green leafy vegetable. In O.U. Eka (eds), Nutritional Quality of Plant Foods (pp. 120-133). Benin City: Post-Harvest Research publications

[17] Ejoh, A., Tchouanguep, M. \& Fokou, E. (1996). Nutritional composition of the leaves and flowers of Colocosia esculenta and the fruits of Solanum melongena. Plant food for human nutrition, 49: 107-112.

[18] John Purseglove: A Pioneer of Rural Development. By E. Clayton. Ashford, Kent: Wye College Press (1993), ISBN 086266-061-0. 